\title{
Augmented boiling on copper-graphite composite surface
}

\author{
WEN-JEI YANG and H. TAKIZAWA \\ Department of Mechanical Engineering and Applied Mechanics, University of Michigan, \\ Ann Arbor, MI 48109, U.S.A. \\ and \\ D. L. VRABLE \\ Division of Thermal \& E.M. Components Technology, Sparta Inc., 9455 Town Center Drive, \\ San Diego, CA 92121, U.S.A.
}

(Received 5 March 1990 and in final form 10 December 1990)

\begin{abstract}
An experimental study is conducted to determine the nucleate pool boiling heat transfer performance of a copper-graphite ( $\mathrm{Cu}-\mathrm{Gr})$ composite surface in Freon 113. The composite medium consists of ultra-high thermal conductivity graphite fibers of $0.0008-0.010 \mathrm{~mm}$ diameter being consolidated in a copper matrix (50\% area fraction). It has high thermal conductivity along the fiber directions, several times those in the other two directions. The heating surface is constructed with a $\mathrm{Gr}-\mathrm{Cu}$ composite plate of $25 \mathrm{~mm}$ diameter and $10 \mathrm{~mm}$ thick. The boiling heat fiux in the nucleate regime is compared to isotropic pure copper used as the heating surface. It is disclosed that the boiling heat transfer coefficients on the composite surface are higher than those on the copper surface by a factor of over 6 to 3, respectively at lower and higher values of superheating. Hence, the composite surface may serve as a high heat flux boiling surface with the merits of no extra pressure drop, no fouling and low cost.
\end{abstract}

\section{INTRODUCTION}

THE DEVELOPMENT of high performance heat transfer surfaces is an important mission of heat transfer research. The immediate advantages of high performance surfaces are numerous: for example, more energy extraction or utilization from an energy source (especially low energy-density sources), more energy recovery from waste heat, efficient cooling of electronic components, compact and light weight which are important in vehicular applications, etc. It is well known that the practical use of the Sterling engine in automobiles is hinged on the size of heat exchangers and that the feasibility of an OTEC (ocean thermal energy conversion) plant for power generation is hampered by the size of its boiler and condenser.

The application for highly effective high heat flux surfaces for electronic chips (very large-scale integration, VLSI) cooling is required to keep pace with the evolving chip technology. Higher computer speeds require more circuit power packaged in smaller volumes. This will require improved heat transfer surfaces to deal with the higher heat flux requirements. Figure 1 [1] shows the trend of the heat flux at the module level in several computer systems. The success of nucleate boiling in these applications will be dependent on (1) how to initiate boiling, and (2) how to extend the burnout points. Bergles and Chyu [2] conducted research to assess boiling enhancement using various surfaces. Other researchers evaluated direct applications of electronic chip cooling by attaching the high heat flux surface to the structure of the chip. For example, Nakayama et al. [3] investigated the boiling performance of heat sink studs with enhanced surfaces and Oktay et al. [4] reported high heat flux capability using a tunnel heat sink.

Rapid advances were made in the development of special nucleate boiling geometries since the early 1960s [5, 6]. Many potential measures have been suggested [7]. Today, six nucleate boiling geometries are commercially available [5]. Two basic approaches are

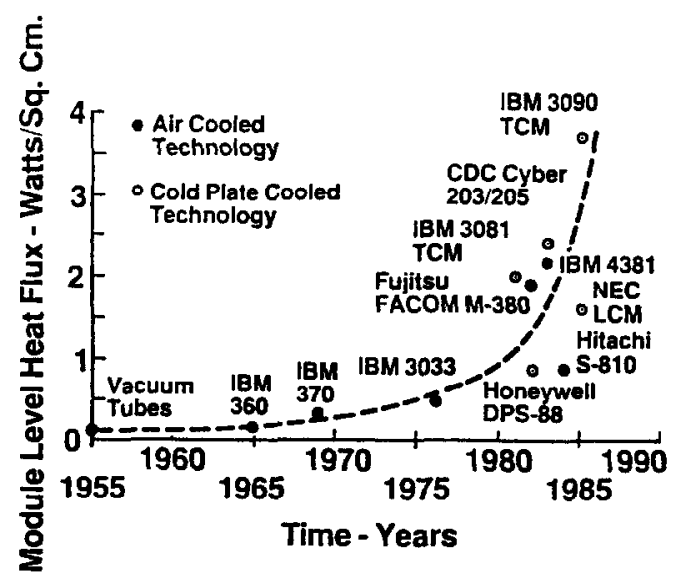

FIG. 1. The trend in heat flux at the module level [1]. 


\section{NOMENCLATURE}

$A$ heat transfer area $\left[\mathrm{m}^{2}\right]$

$h_{\mathrm{b}} \quad$ boiling heat transfer coefficient [W $\mathrm{W}^{-2} \mathrm{~K}^{-1}$ ]

$k$ thermal conductivity of $\mathrm{Gr}-\mathrm{Cu}$ [W $\left.\mathrm{m}^{-1} \mathrm{~K}^{-1}\right]$

$L \quad$ distance between thermocouples [m]

$q$ rate of heat transfer [W]

$T$ temperature $[\mathrm{C}]: T_{\mathrm{f}}$, of liquid; $T_{\mathrm{s}}$, of heating surface; $T_{\text {sat }}$, saturate temperature
$\Delta T$ temperature difference $[\mathrm{C}]: \Delta T_{x}$, between two locations at a distance of $L ; \Delta T_{s}$, $T_{\mathrm{s}}-T_{\mathrm{sit}}$.

$\begin{array}{cl}\text { Subscripts } \\ f & \text { liquid } \\ s & \text { heating surface } \\ \text { sat } & \text { saturate liquid } \\ x & \text { local. }\end{array}$

employed to form a high area density of nucleation sites: porous boiling surfaces (PBS) and integral 'roughness' surface (IRS). PBS consists of a sintered, porous, metallic matrix bonded to a base surface. The sintered porous coating is approximately $0.25 \mathrm{~mm}$ thick, with a $50-65 \%$ void fraction. The average pore radius ranges from 0.01 to $0.1 \mathrm{~mm}$ which functions as sites for generation of vapor bubbles. Union Carbide, Linde Division has developed such a PBS, called UC high flux surface [8]. In the case of integral roughness, the metal is cold worked to form re-entrant nucleation sites which are interconnected below the surface. The groove opening at the surface is a critical dimension, $0.0038-0.0089 \mathrm{~mm}$ for Refrigerant 11 [9]. The performance is sharply diminished for a gap width outside of this range. The preferred gap spacing is expected to be higher for high surface tension fluids. Thermoexel developed by Hitachi [10] is a surface formed from an integral-fin tube, which has small spaced contours at the fin tips. These 'saw tooth' fins are bent to a horizontal position to form tunnels with spaced pores at their top. The liquid in the tunnels is heated rapidly and shanges to vapor which leaves through openings as bubbles. Part of the vapor always remains in the tunnels and thus, boiling occurs continuously. Another nucleate boiling roughness geometry by Weiland Werke A.G. is formed from standard $7.5 \mathrm{fins}^{-1}$ integral-fin-tubing [11]. However, the special surface geometries employed for enhancement of nucleate pool boiling generally cannot be applied to forced convection vaporization inside tubes, with the exeeption of the Linde PBS.

Similar to PBS, porous condensing surfaces (PCS) formed by attached metal particles bave been developed for condensation of vertical tubes [12] and forced condensation inside tubes [13]. An array of small metal particles, $0.25-1.0 \mathrm{~mm}$ high, covers 20 $60 \%$ of the surface [12]. In the case of condensation on vertical tubes, condensation occurs on the particle array (i.e. convex surfaces of the particles) and drains along the smooth base surface. In the case of forced condensation inside tubes, the spaced metal particles provide an extended surface at high vapor qualities and turbulence of the film at lower vapor qualities.

The use of PBS (and PCS in condensation) and IRS suffers from the pressure drop (although relatively small), the loss of enhancement efficiency due to fouling (to plug up pores and re-entrant cavities) and, most important of all, the cost of fabrication and maintenance.

Several investigations have been conducted to evaluate the effect of isotropic surface thermal properties on boiling and condensation [14-18]. Recently, Wright and Gebhart [19] performed pool boiling experiments on vertical, smooth and regularly microconfigured etched silicon surfaces in saturated water at $1 \mathrm{~atm}$. All specimens were $1.27 \mathrm{~cm}$ square and approximately $300 \mu \mathrm{m}$ thick. In the nucleate boiling regime, the hexagonally dimpled and trenched specimens had a heat transfer increase of a factor of 4.2 and 3.1 , respectively, over that of the smooth specimens. However, the localized effect of an isotropic high thermal conductivity perpendicular to the surface has not been evaluated. The aim of this paper is to experimentally investigate nucleate pool boiling performance of advanced conper-graphite ( $\mathrm{Cu}-\mathrm{Gr}) \mathrm{com}$ posite surfaces. The boiling heat flux in the nucleate boiling regime is compared to isotropic pure copper used as the heating surface. In comparison with the conventional high heat flux boiling surfaces, the $\mathrm{Cu}$ Gr surface causes no extra pressure drop, is free from fouling and benefits from low primary and maintenance costs.

\section{FEATURE OF COPPER-GRAPHITE COMPOSITE}

The graphite fiber reinforced copper ( $\mathrm{Gr}-\mathrm{Cu}$ ) produced by SPARTA consists of graphite fiber of 0.008 $0.010 \mathrm{~mm}$ diameter imbedded uniaxially within a copper matrix (50\% area fraction). Figure 2 illustrates the photomicrographs of the surface. The higher fiber thermal conductivity is three times larger than the adjacent matrix conductivity. The fibers act as highly efficient pin fins that penetrate into the heat transfer surface. The effect of the local high conductivity fibers may be to enhance the conduction path into or away from the surface fluid and increase the surface nucleation site activity. The effect would be a thermal enhancement that is provided by tailored thermal 

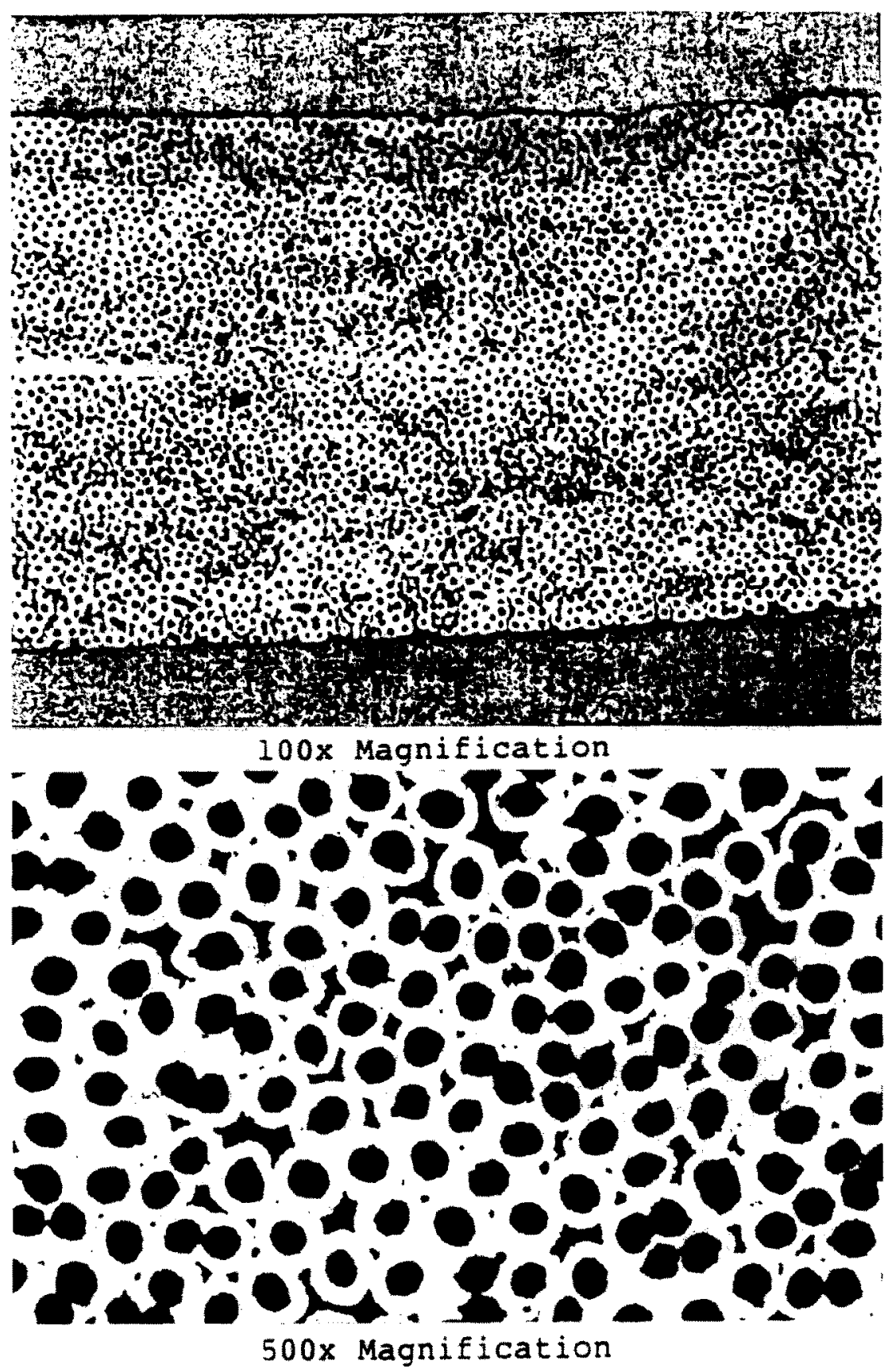

FIG. 2. Photomicrographs of the surface on a graphite fiber reinforced copper composite produced by SPARTA.

properties internal to the heat transfer surface. Key properties in the $\mathrm{Gr}-\mathrm{Cu}$ composites include (i) high thermal conductivity in the fiber direction of up to $1200 \mathrm{~W} \mathrm{~m}^{-1} \mathrm{~K}^{-1}$ for the advanced pitch based graphite fiber, as compared with $401 \mathrm{~W} \mathrm{~m}^{-1} \mathrm{~K}^{-1}$ for pure copper at $300 \mathrm{~K}$; (ii) low density at $6.14 \mathrm{~g} \mathrm{~cm}^{-3}$, lighter than pure copper with $8.93 \mathrm{~g} \mathrm{~cm}^{-3}$. Other unique aspects of this material are a modulus near 140 Msi and a negative coefficient of thermal expansion. By controlling both the directional layup and the volume fraction of the fiber, the directional conductivity, coefficient of thermal expansion, strength and stiffness can be tailored to optimize the thermal/structural performance of the cooling concept.

The hypothesis is that the high thermal conductivity fiber (perpendicular to the boiling surface) may provide an intrinsic enhancement of heat transfer, bubble formation and departure frequency. The fiber diameter of $0.008 \mathrm{~mm}$ is comparable to the critical size for the bubble nucleation sites in boiling water. It is smaller than those of pores on pool boiling surfaces and re-entrant cavities on integral 'roughness' surfaces. Hence, each fiber tip on the surface may act as a site activator for bubble nucleation. The local 
high thermal conductivity provides a more efficient conduction path to or from the surface nucleate site.

\section{POOL BOILING APPARATUS AND TEST PROCEDURE}

Figure 3 depicts a pool boiling experimental apparatus. The heating surface was constructed with a $\mathrm{Gr}$ $\mathrm{Cu}$ composite plate $25 \mathrm{~mm}$ in diameter and $10 \mathrm{~mm}$ thick. Being polished with a $1 \mu \mathrm{m}$ diamond abrasive, it was attached to a heating copper block of $25 \mathrm{~mm}$

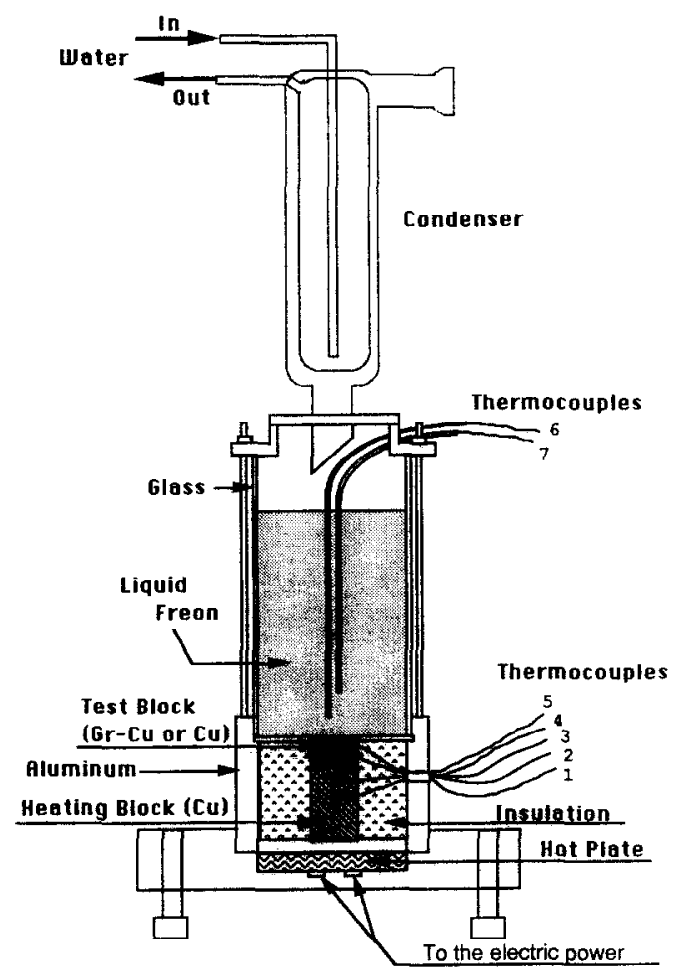

Fig. 3(a). A schematic of the pool boiling apparatus.

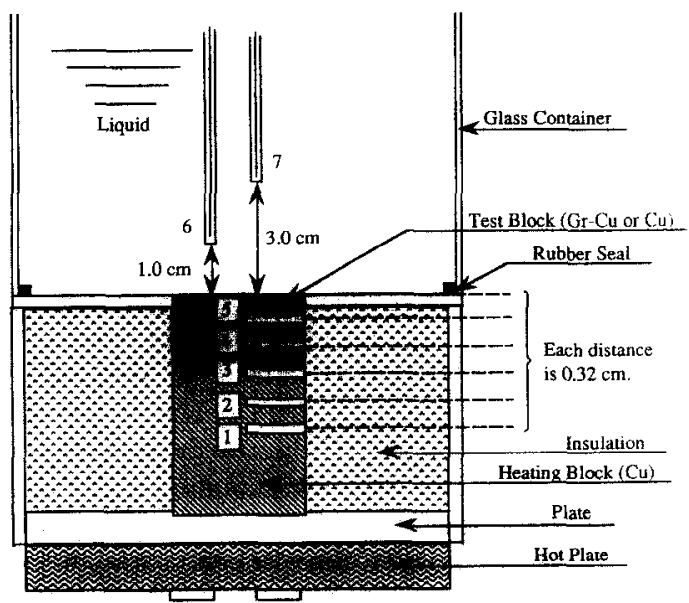

FIG. 3(b). Detailed information of thermocouple positions. diameter and $41 \mathrm{~mm}$ long. The lower end of the copper block was in contact with an electrically heated hot plate. Three 30-gage copper-constantan thermocouples (Nos. 1, 2 and 3) were installed in the copper block at a $3.2 \mathrm{~mm}$ interval on the centerline, with one at the composite-copper interface. Two similar thermocouples (Nos. 4 and 5) were placed in the composite plate also at a $3.2 \mathrm{~mm}$ interval from its interface with the copper block. Their temperature measurements were used to determine the boiling surface temperature $T_{\mathrm{s}}$ through a linear extrapolation of $T_{4}$ and $T_{5}$. The heat flux through the composite into the liquid was calculated using the temperatures from thermocouple readings and the distance between the thermocouples. Two 30-gage copper-constantan thermocouples (Nos. 6 and 7) measured saturated liquid temperatures $\left(T_{\text {sat }}\right)$. A recorder/datalogger manufactured by Wahl Instruments, Inc., Culver City, California, was employed for temperature recordings.

Both the $\mathrm{Gr}-\mathrm{Cu}$ composite and copper blocks were insulated around the surfaces in a glass container of circular cross section. The edge of the upper end of the composite block was undercul with a bevel and an undersize thin stainless-steel mating piece was attached by a shrink fit to provide a continuous surface to keep heat loss by conduction at a minimum. Power input (heat flux) was varied to cover the nucleate boiling regime. Freon 113 with a boiling point of $47.1^{\circ} \mathrm{C}$ was selected as the boiling liquid.

A condenser mounted on the top of the test-vessel cover served to condense the vapor formed. At the lower heat-flux rates, it was possible to control the temperature of the test refrigerant by varying the cooling-water flow rate and thus obtained limited data for boiling of a subcooled liquid.

Another experiment was conducted with the Gr$\mathrm{Cu}$ composite replaced with a pure copper surface (isotropic properties) in order to provide a baseline for the expcrimental study. The only difference between the two surfaces was the internal thermal conductivity.

\section{EXPERIMENTAL RESULTS}

To the knowledge of the authors, this is the first experimental study of boiling on fiber reinforced composite surface. Two Gr- Cu surfaces and one pure copper surface were used to boil Freon 113. After filling the test vessel with Freon 113, power was lurned on and the liquid was boiled rigorously for a period of time. The liquid depth at filling in all cases was 11 $\mathrm{cm}$. The variation in $T_{\text {sat }}$ resulted solely from the change in hydrostatic pressure with depth when the cooling-water rate was maintained constant. The liquid bulk temperature $T_{\mathrm{f}}$ or $T_{\mathrm{sal}}$ could be controlled by varying the cooling-water flow rate. The difference between $T_{\text {sat }}$ and $T_{\mathrm{f}}$ is the degree of subcooling. In temperature recordings, which are not shown here, the temperature rise is nearly linear, begins to level off 
at about $15 \mathrm{~min}$ and reaches a steady state at $20 \mathrm{~min}$. Hence, at every change in the power input, the steady temperatures were read after a duration of $20 \mathrm{~min}$.

In every test scries, power input was raised from a low value to a maximum and lowered to the original value at the same power interval. Figure 4 reveals that the boiling heat transfer coefficient $h_{\mathrm{b}}$ underwent the phenomenon of hysteresis with $h_{\mathrm{b}}$ taking higher values for increasing $\Delta T_{\mathrm{s}}$ than that for decreasing $\Delta T_{\mathrm{s}}$. Here, $h_{\mathrm{b}}$ is defined as

$$
h_{\mathrm{b}}=\frac{\frac{q}{A}}{\Delta T_{\mathrm{s}}}=\frac{k \Delta T_{x}}{L \Delta T_{\mathrm{s}}}
$$

where $\Delta T_{\mathrm{s}}$ is the difference between the surface temperature $T_{\mathrm{s}}$ and the saturated liquid temperature $T_{\text {sat }}$, which was measured by thermocouple $7 . k$ denotes the thermal conductivity of $\mathrm{Gr}-\mathrm{Cu}$ which is $1000 \mathrm{~W}$ $\mathrm{m}^{-1} \mathrm{~K}^{-1}$ and the thermal conductivity of copper which is $401 \mathrm{~W} \mathrm{~m}^{-1} \mathrm{~K}^{-1} . \Delta T_{x}$ is the temperature difference between two locations (thermocouples 4 and 5) at a distance of $L(3.2 \mathrm{~mm})$. Sometimes, the hysteresis loop is crossed over, as illustrated in Fig. 4(b).

Figure 5 shows the variation of $\Delta T_{s}$ with power input, which is a straight line for power exceeding 20 V. The variation is a concave curve at low power inputs, $0-20 \mathrm{~V}$. The variation of $h_{\mathrm{b}}$ with power input is shown in Fig. 6. It is a straight line through the origin. The data scattering is approximately $\pm 100 \%$ which can be partially attributed to gradual oxidation of the heater surface. Other factors which contribute to data scattering include subcooling, liquid depth and cooling-water rate.

The nucleate boiling heat transfer performance is depicted in Fig. 7, hollow squares for the Gr-Cu surface $\left(k=1000 \mathrm{~W} \mathrm{~m}^{-1} \mathrm{~K}^{-1}\right)$ and solid square for the pure copper surface $\left(k=400 \mathrm{~W} \mathrm{~m}^{-1} \mathrm{~K}^{-1}\right)$. The value of $h_{\mathrm{b}}$ for $\mathrm{Gr}-\mathrm{Cu}$ is higher than that for pure copper by a factor of over 6 to 3, respectively at lower and higher values of superheating, $\Delta T_{\mathrm{s}}$.

(a)

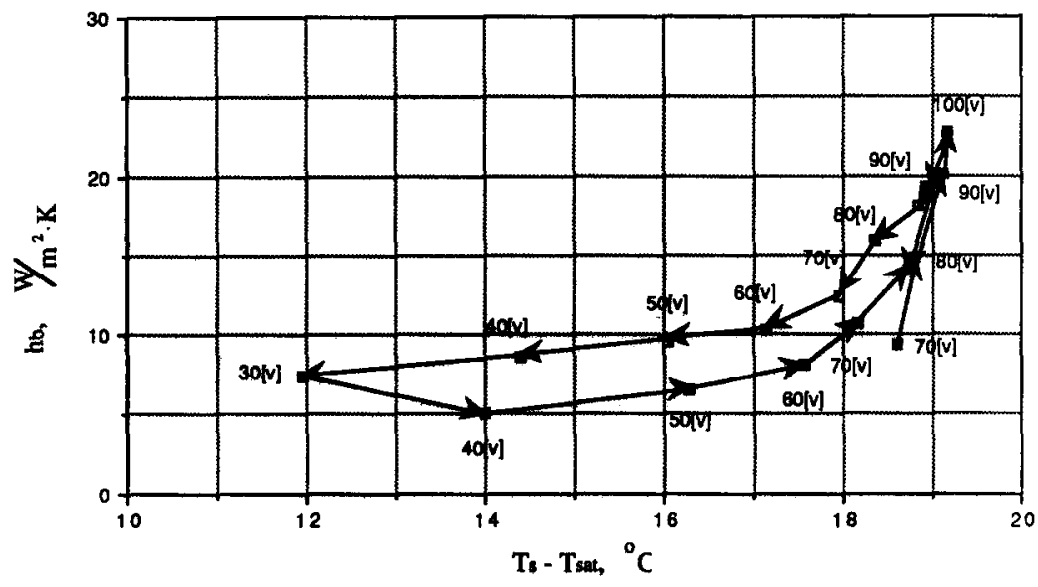

(b)

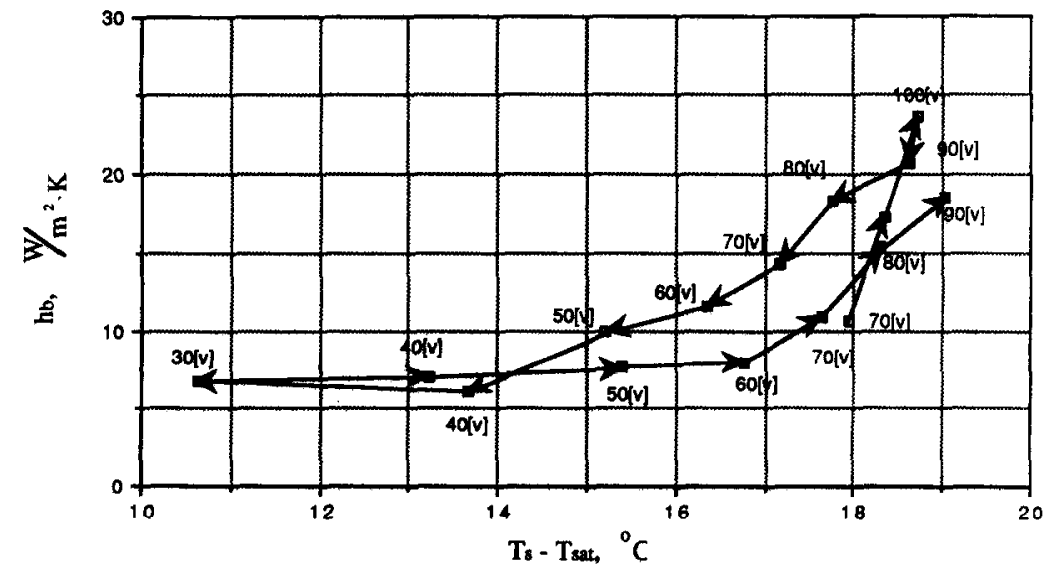

FIG. 4. Plots of $h_{\mathrm{b}}$ vs $T_{\mathrm{s}}-T_{\text {sat }}$ for test cycles for a composite surface. 


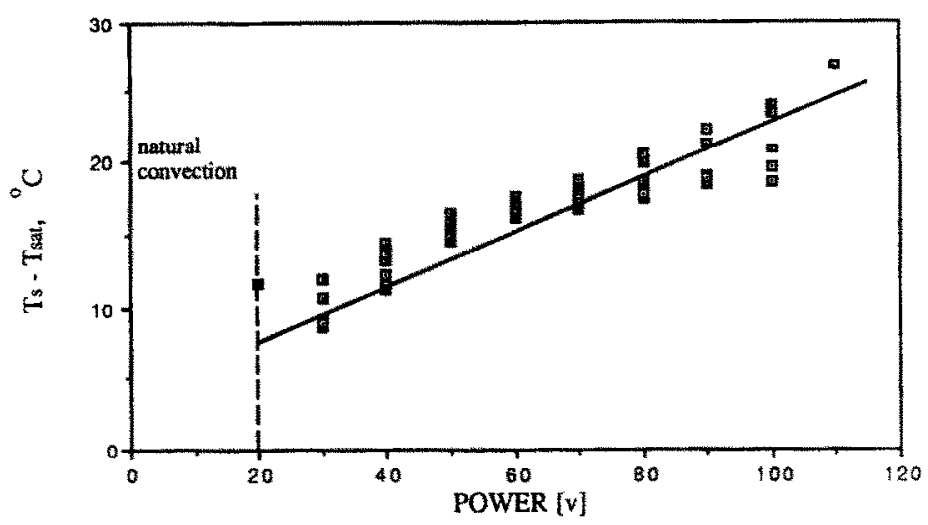

F10. 5. Plots of $T_{s}-T_{\mathrm{sal}}$ vs power for a composite surface.

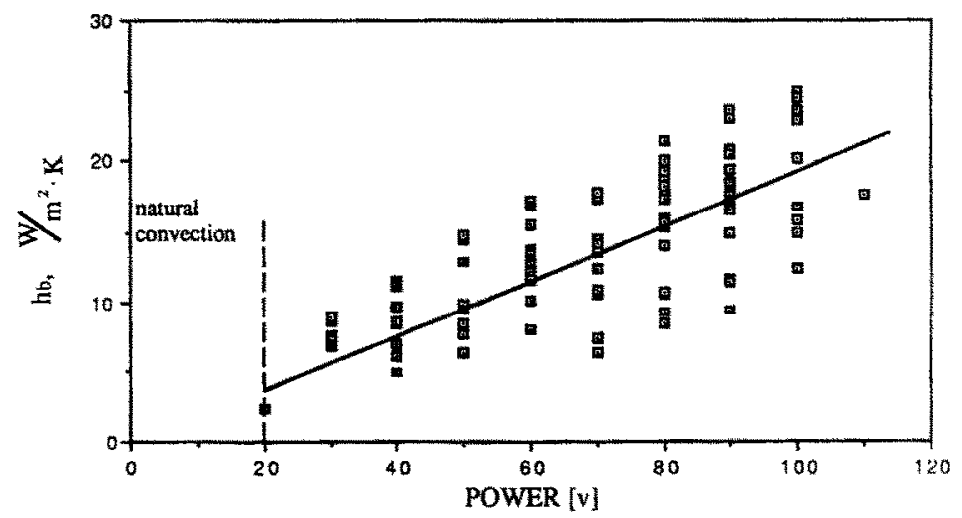

Flo. 6. Plots of $h_{b}$ vs power for a composite surface.

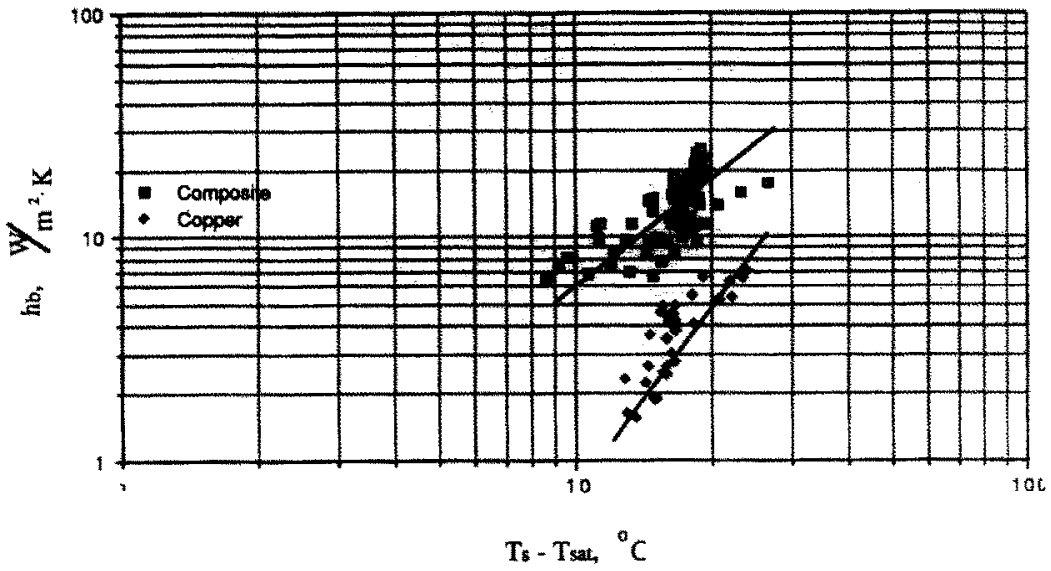

FrG. 7. Plots of $h_{6}$ vs $T_{s}-T_{\text {sat }}$ for both composite and copper surfaces.

\section{CONCLUSION AND REMARK}

The reproductivity of test data for nudeate pool bolling of Freon 113 on the $\mathrm{Cu}-\mathrm{Gr}$ composite surface is good, with large scattering. Like boiling of Freon 113 on a purc copper surface, oxidation occurs on the composite surface. It is revealed from this study that the nucleate boiling heat transfer coefficients on the composite surface are higher than those on the pure copper surface by a factor of over 6 to 3 , respectively at lower and higher values of superheating. The disclosure warrants more studies on the nucleate boiling heat transfer of other liquids on the composite surface:

An attempt was made during the study to investigate the hypothesis that each tip of the high thermal conductivity fiber on the surface may act as a site 
activator for bubble nucleation. However, the nucleation of too many bubbles on the surface made it impossible to match nucleation sites with fiber tips. A future study is planned to prove the hypothesis using a surface with only a few fibers. Upon the validation of the hypothesis, the nucleation site cavity can be enhanced by selective tailoring of the internal characteristics of the boiling surface.

Acknowledgement-The study was supported by the National Science Foundation under grant number CBT8811065 .

\section{REFERENCES}

1. R. C. Chu and R. E. Simmons, Heat transfer in large scale composites, Heat Transfer: Korea-U.S. Seminar on Thermal Engineering and High Technology (Edited by J. Kim, Sung Task Ro and Taik Sik Lee). Hemisphere, Washington, DC (1986).

2. A. E. Bergles and M. C. Chyu, Characteristic of nucleate boiling from porous metallic coatings, $J$. Heat Transfer 104, 279-285 (1982).

3. W. Nakayama, T. Nakajima and S. Hirasawa, Heat sink studs having enhanced boiling surfaces for cooling of microelectronic components, ASME Paper No. 84WA/HT-89m (1984).

4. S. Oktay, G. Torgersen and A. Wong, Bubble generating tunnels for cooling semiconductor devices, U.S. Patent 4, 203, 129, 23 May (1980).

5. R. L. Webb, High performance heat transfer surfaces for boiling and condensation. In Heat Transfer in Energy Problems (Edited by T. Mizushima and Wen-Jei Yang), pp. 127-132. Hemisphere, Washington, DC (1983).

6. K. Nishikawa and T. Ito, Augmentation of nucleate boiling heat transfer by prepared surfaces. In Heat Transfer in Energy Problems (Edited by T. Mizushima and Wen-Jei Yang), pp. 119-126. Hemisphere, Washington, DC (1983).
7. R. L. Webb, G. A. Junkhan and A. E. Bergles, Bibliography of U.S. patents of augmentation of convective heat and mass transfer, Engineering Research Institutes, Iowa State University, Ames, Iowa (1980).

8. C. F. Guttzman, J. B. Wulf and P. S. O'Neill, Theory and application of high performance boiling surfaces to components of absorption cycle air conditioners, Proc. Conf. on Natural Gas Res. and Technol. (1971).

9. R. L. Webb, Heat transfer surface which promotes nucleate ebullition, U.S. Patent 3, 521, 708 (1972).

10. N. Arai, T. Fukushima, A. Arai, T. Nakajima, K. Fujii and W. Nakayama, Heat transfer tubes enhancing boiling and condensation in heat exchangers of a refrigerating machine, Trans. ASHRAE 83, 58-70 (1977).

11. Anon, GEW A-T-tubes: high performance lubes for flooded evaporators, Brochure SAE15e-06.78, WelandWerke Act, Metabuerke, Ulam, F.R.G. (1978).

12. F. Notaro, Enhanced condensation heat transfer device and method, U.S. Patent 4, 154, 294 (1979).

13. G. W. Fenner and E. Ragi, Enhanced tube inner surface heat transfer device and method, U.S. Patent 4, 154, 293 (1979).

14. A. Singh, B. B. Mikic and W. M. Rohsenow, Effect of superheat and cavity size on frequency bubble departure in boiling, Trans. ASME 99, $246-249$ (1977).

15. R. J. Hannemann and B. B. Mikic, An experimental investigation into the effect of surface thermal conductivity of the rate of heat transfer in dropwise condensation, Int. J. Heat Mass Transfer 19, 1309-1317 (1976).

16. P. Griffith and M. Lee, The effect of surface thermal properties and finish on dropwise condensation, $I n t . J$. Heat Mass Transfer 10, 697-707 (1967).

17. S. Aksan and J. Rose, Dropwise condensation-the effect of thermal properties of the condenser materials, Int. J. Heat Mass Transfer 18, 261-267 (1975).

18. J. S. Horowitz and B. B. Mikic, Effect of surface thermal properties on dropwise condensation, Proc. Int. Heat Transfer Conf., Tokyo, Vol. III, pp. 259-263 (1974).

19. N. Wright and B. Gebhart, Enhanced boiling on microconfigured surfaces, J. Electronic Packing 111, 112-120 (1989).

\title{
EBULLITION ACCRUE SUR UNE SURFACE COMPOSITE CUIVRE-GRAPHITE
}

\begin{abstract}
Résumé-Une étude expérimentale est conduite pour déterminer les performances de transfert thermique par ébullition nucléé d'une surface composite cuivre graphite ( $\mathrm{Cu}$ Gr) dans du Freon 113. Le milieu composite en fibres de graphite à très haute conductivite thermique de $0,0008-0,010 \mathrm{~mm}$ de diamètre, dans une matrice de cuivre ( $50 \%$ de fraction d'aire). La conductivite thermique dans les directions des fibres est plusieurs fois celles dans les deux autres directions. La surface de chauffage est construite avec une plaque composite $\mathrm{Cu}-\mathrm{Gr}$ de $25 \mathrm{~mm}$ de diamètre et de $10 \mathrm{~mm}$ d'épaisseur. Le fiux thermique dans le régime nucléé esl comparé au cas du chauffoir en cuivre pur. Les coefficients de transfert sur la surface composite sont plus grands d'un facteur entre 6 et 3 par rapport au cuivre pur, respectivement pour la plus faible et la plus forte valeur de surchauffe. La surface composite peut servir comme surface à haut flux à l'ébullition avec

les avantages d'aucune perte de pression supplémentaire, d'aucun encrassement et d'un coût faible.
\end{abstract}

\section{INTENSIVIERTES SIEDEN AN EINER GRAPHITDOTIERTEN KUPFEROBERFLÄCHE}

\begin{abstract}
Zusammenfassung-Der Wärmeübergang beim Behältersieden an einer graphitdotierten Kupferoberfläche $(\mathrm{Gr}-\mathrm{Cu})$ wird mit $\mathrm{R} 113$ experimentell untersucht. Dieses Material besteht aus Graphitfasern von extrem hoher Wärmeleitfähigkeit und Durchmessern im Bereich $0,0008-0,010 \mathrm{~mm}$, die in eine Kupfermatrix eingelagert sind ( $50 \%$ Flächenanteil). Die Wärmeleitfähigkeit in Längsrichtung der Faser ist mehrfach größer als in die beiden anderen Richtungen. Die Heizfläche besteht aus einer Gi-Cu Plalle mit $25 \mathrm{~mm}$ Durchmesser und $10 \mathrm{~mm}$ Dicke. Die Wärmestromdichte bei den Blasensiedeversuchen ist von gleicher Größenordnung wie diejenige bei einer isotropen reinen Kupferplatte. Es zeigt sich, daß die Wärmeübergangskoeffizienten an der neuen Platte um einen Faktor $3-6$ größer sind als diejenigen an der Kupferoberfläche, was einer geringeren bzw. größeren Überhitzung entspricht. Die neue Oberfläche kann deshalb als Hochleistungssiedefläche dienen mit folgenden Vorteilen: kein zusätzlicher Druckverlust, keine Verschmutzung und niedrige Kosten.
\end{abstract}




\section{ИНТЕНСИВНОЕ КИПЕНИЕ НА ПОВЕРХНОСТИ КОМПОЗИТА МЕДЬ-ГРАФИТ}

Аннотацня-Проводится экспериментальное исследование с целью определения характеристик теплопереноса при пузырьковом кипении в большом объеме, вызванном композитом медьграфит, помещенным в хладагент 113. Композитная среда состоит из обладающих сверхвысокой теплопроводностыю графитовых волокон диаметром 0,0008-0,010 мм, отвердевающих в медной матрице (доля их плоцади составляет $50 \%$ ). Матрица имеет высокую теплопроводность в направлении волокон, которая в несколько раз больше. чем в двух других направлениях. Поверхность нагрева представляет собой пластину из композита диаметром 25 мм и толщиной $10 \mathrm{Mм.} \mathrm{Тепло-}$ вой поток при кипении в пузырьковом режиме сравнивается со случаем изотропной чистой меди, используемой в качестве поверхности нагрева. Показано, что коэффициенты теплопереноса при кипении на композитной поверхности превышают полученные для медной поверхности более, чем в 6 и 3 раза соответственно при низких и высоких значениях перегрева. Следовательно, композитная поверхность может служить поверхностью кипения при большом тепловом потоке благоларя таким преимуществам, как отсутствие избыточного перепада дарления и погрешностей измереннй приборов, а также низкие затраты. 